\title{
Analisis Highest and Best Use Pada Lahan Kosong Di Jalan Raya Diponegoro Nomor 110-112 Surabaya
}

\author{
Yehezkiel Fridly Timang dan Retno Indryani \\ Departemen Teknik Sipil, Fakultas Teknik Sipil dan Perencanaan, Institut Teknologi Sepuluh \\ Nopember (ITS) \\ e-mail: yehezkiel.fridly@gmail.com
}

\begin{abstract}
Abstrak-Nilai suatu lahan ditentukan oleh penggunaan properti pada lahan tersebut. Penggunaan properti yang tepat akan memberikan nilai lahan yang tinggi dan baik. Penentuan penggunaan properti yang akan memberikan nilai lahan yang tertinggi dan terbaik dapat dilakukan dengan analisis Highest and Best Use. Dalam penelitian ini, lahan yang akan dianalisis menggunakan metode Highest and Best Use terletak di Jalan Raya Diponegoro nomor 110-112 Surabaya. Analisis Highest and Best Use akan meminjau aspek legal dan aspek fisik lahan kosong yang ditinjau sehingga menghasilkan beberapa pilihan alternatif penggunaan properti. Alternatif penggunaan yang ada ditinjau kelayakan aspek finansialnya. Alternatif penggunaan yang dinyatakan layak secara finansial akan ditinjau lagi aspek produktivitas maksimumnya sehingga menghasilkan nilai lahan dari alternatif penggunaan tersebut. Alternatif penggunaan yang memiliki nilai lahan tertinggi adalah pilihan pengunaan properti yang dapat dikembangkan di lahan kosong tersebut. Hasil dari penelitian ini diperoleh bahwa alternatif penggunaan properti berupa perkantoran yang cocok untuk dikembangkan di lahan kosong yang ditinjau dengan nilai lahan tertinggi sebesar Rp 80.627.669,383/m².
\end{abstract}

Kata kunci-HBU, Lahan Kosong, Penggunaan Tertinggi dan Terbaik

\section{PENDAHULUAN}

$\mathrm{J}$ UMLAH penduduk Surabaya yang semakin mengalami peningkatan.menyebabkan kebutuhan akan penggunaan tanah atau lahan juga meningkat. Penggunaan lahan yang dimaksud dapat berupa pembangunan perumahan, apartemen, hotel, gedung perkantoran, ataupun kompleks pertokoan. Salah satu kawasan di Surabaya yang memiliki lahan kosong yang semakin sedikit adalah Jalan Raya Diponegoro tepatnya lahan kosong tersebut berlokasi di Jalan Raya Diponegoro Nomor 110-112 (Gambar 1). Lahan tersebut memiliki luas sebesar $3.584 \mathrm{~m}^{2}$, terletak di antara bangunan, dan memiliki status tanah sebagai hak guna bangunan. Kawasan ini merupakan kawasan pemukiman penduduk sekaligus juga perkantoran dan jasa komersial lainnya.

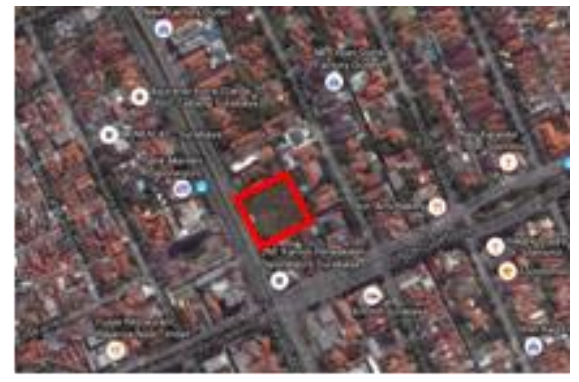

Gambar 1. Lokasi Lahan Kosong Di Jalan Raya Diponegoro Nomor 110112 Surabaya

Lahan tersebut dapat memberikan nilai lebih jika dikembangkan menjadi suatu properti. Nilai yang dihasilkan oleh suatu lahan ditentukan oleh penggunaan properti pada lahan tersebut. Nilai lahan yang tinggi dan baik dihasilkan oleh penggunaan properti yang tepat. Pemilihan properti yang tepat dapat dilakukan melalui analisis Highest and Best Use.

Analisis Highest and best use (HBU) merupakan suatu analisis tentang penggunaan terbaik atau tertinggi dari suatu lahan kosong. Analisis ini terdiri dari beberapa aspek yaitu, aspek kelayakan secara legal, aspek kelayakan secara fisik, aspek kelayakan secara finansial, dan aspek produktivitas secara maksimal.Sebuah properti dikatakan memenuhi syarat atau kriteria HBU jika secara legal diijinkan, memungkinkan secara fisik, layak secara finansial, dan dapat memberikan hasil yang maksimal.

Adapun tujuan dari penelitian ini adalah untuk mendapatkan jenis properti komersial yang secara legal diijinkan, secara fisik memungkinkan, secara finansial menguntungkan dan dapat memberikan nilai lahan yang terbaik dan tertinggi.

\section{TINJAUAN PUSTAKA}

\section{A. Konsep Highest And Best Use}

Highest and best use atau penggunaan tertinggi dan terbaik didefinisikan sebagai kemungkinan rasional dan sah penggunaan tanah atau properti yang sudah dikembangkan yang secara fisik dimungkinkan, mendapatkan dukungan yang cukup dan secara finansial layak dan menghasilkan nilai yang tertinggi [1]. Aspek-aspek yang perlu dipertimbangkan dalam menganalisis penggunaan yang terbaik dan tertinggi adalah aspek legal, aspek fisik, aspek finansial, dan aspek produktivitas maksimum.

1. Aspek Legal 
Aspek legal merupakan hal-hal yang berkaitan dengan hukum atau peraturan-peraturan yang berlaku dalam pemerintahan. Aspek legal harus memenuhi syarat-syarat peraturan bangunan, penataan wilayah kota, dan peraturan lingkungan [2].

2. Aspek Fisik

Penggunaan suatu lahan untuk dijadikan sebagai tempat berdirinya suatu properti harus memperhatikan kondisi lahan tersebut.Ukuran, bentuk, daerah, kemiringan dan asesssibilitas suatu lahan berdampak pada penggunaan pengembangan lahan.

3. Aspek Finansial

Dalam menentukan penggunaan yang terbaik dari suatu lahan, hanya alternatif penggunaan yang memenuhi kriteria aspek fisik dan aspek legal yang dapat dipertimbangkan lebih lanjut. Alternatif penggunaan tersebut akan dikaji apakah dapat mendatangkan pendapatan atau pengembalian yang seimbang bahkan lebih tinggi daripada jumlah yang dibutuhkan untuk menutup biaya pembangunan dan operasional.

\section{Aspek Produktivitas Maksimum}

Dari berbagai alternatif penggunaan yang layak secara finansial, alternatif yang menghasilkan nilai tanah residual yang tertinggi dan konsisten dengan tingkat pengembalian yang dijamin oleh pasar adalah alternatif penggunaan yang tertinggi dan terbaik. Nilai residual tanah dapat ditemukan dengan mengestimasi nilai alternatif penggunaan yang diusulkan dan menguranginya dengan nilai bangunan alternatif.Nilai bangunan alternatif diperoleh berdasarkan hasil perhitungan biaya investasi bangunan sedangkan nilai alternatif penggunaan diperoleh dengan menggunakan metode pendekatan pendapatan di masa mendatang yang telah didiskontokan menjadi nilai sekarang.

\section{METODOLOGI PENELITIAN}

Metode yang digunakan dalam penelitian ini dapat dilihat pada Gambar 2.

\begin{tabular}{|c|}
\hline $\begin{array}{l}\text { Latar Belakang } \\
\text { 1. Kebutuhan lahan di Surabaya meningkat sedangkan } \\
\text { ketersediaan lahan terbatas. } \\
\text { 2. Pengoptimalan penggunaan lahan di Jalan Diponegoro. }\end{array}$ \\
\hline $\begin{array}{l}\text { Perumusan Masalah } \\
\text { Jenis properti komersial apa yang dapat memberikan nilai tertinggi dan } \\
\text { terbaik pada lahan Jalan Raya Diponegoro Nomor 110-112 }\end{array}$ \\
\hline $\begin{array}{l}\quad \text { Tinjauan Pustaka } \\
\text { 1. } \\
\text { 2. } \quad \text { Jensep dasar Properti } \\
\text { 3. Penilaian Properti } \\
\text { 4. }\end{array}$ \\
\hline \begin{tabular}{ll} 
& \multicolumn{1}{c}{ Pengumpulan Data } \\
1. & Data Fisik Lokasi \\
2. & Building Code dan Zoning \\
3. & Biaya Utilitas \\
4. & Data Properti Pembanding
\end{tabular} \\
\hline $\begin{array}{l}\text { Highest and best use } \\
\text { 1. Aspek Legal : Zonning, Peraturan Pemerintah terkait } \\
\text { Bangunan. } \\
\text { 2. Aspek Fisik : Alternatif Penggunaan yang sesuai dengan } \\
\text { luas lahan. } \\
\text { 3. Aspek Finasial :Biaya Investasi, Pendapatan, Pengeluaran, } \\
\text { Diskonto Arus Kas } \\
\text { 4. Aspek Produktivitas Maksimum : Nilai Lahan per } \mathrm{m}^{2}\end{array}$ \\
\hline
\end{tabular}

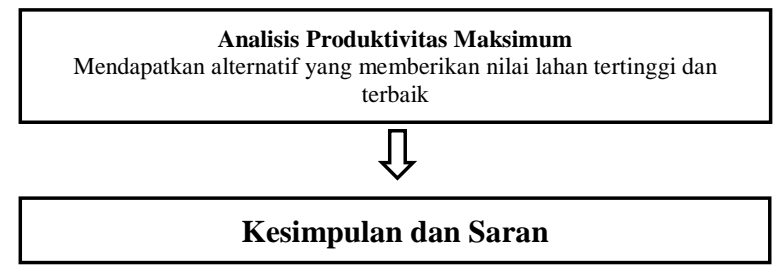

Gambar 2. Diagram Alir Metode Penelitian.

\section{ANALISIS DATA DAN PEMBAHASAN}

\section{A. Analisis Aspek Legal}

Peraturan pemerintah mengenai tata guna lahan di Kota Surabaya diatur dalam Peraturan Daerah Kota Surabaya Nomor 12 Tahun 2014 tentang Rencana Tata Ruang Wilayah Kota Surabaya Tahun 2014-2034. Berdasarkan lokasi objek penelitian, lahan kosong yang ditinjau termasuk dalam Kecamatan Wonokromo yang berada dalam naungan Unit Pengembangan VII Wonokromo.Unit Pengembangan VII Wonokromo memiliki fungsi pengembangan sebagai:

1. Pemukiman Penduduk

2. Perdagangan Barang dan Jasa

3. Kawasan Militer

Ditinjau lebih detail lagi, lokasi objek penelitian yang terletak di Jalan Raya Diponegoro merupakan kawasan yang diperuntukan untuk fungsi pengembangan perdagangan barang dan jasa. Properti komerisal yang termasuk dalam perdagangan barang dan jasa meliputi, pertokoan, perkantoran, pusat perbelanjaan, dan hotel.

\section{B. Analisis Aspek Fisik}

Aspek fisik meliputi aspek teknik yang berhubungan dengan fisik lahan. Data yang dianalisis meliputi lokasi lahan, ketersediaan fasilitas fasilitas publik, dan kesesuaian dimensi lahan dengan alternatif penggunaan. Analisis aspek fisik terdiri dari:

1. Analisis Aspek Fisik Berdasarkan Lokasi Lahan

2. Analisis Aspek Fisik Berdasarkan Ketersediaan Fasilitas Publik

3. Analisis Aspek Fisik Berdasarkan Ukuran dan Bentuk Lahan

\section{Perencanaan Bangunan}

Berdasarkan peraturan pemerintah setempat, rencana bangunan di atas lahan objek penelitian perlu mematuhi aturan-aturan dalam mendirikan sebuah bangunan yang menyangkut sempadan, KDB, KLB, dan KDH [3].

1. Persyaratan Garis Sempadan Bangunan

Garis sempadan bangunan untuk lahan yang ditinjau adalah sebagai berikut .
1. Sisi depan : 6 meter
2. Sisi kanan : 3 meter
3. Sisi kiri : 3 meter
4. Sisi belakang : 3 meter

2. Persyaratan Koefisien Dasar Bangunan (KDB)

Untuk lahan ini, KDB yang dijinkan oleh pemerintah sebesar $60 \%$. Luasan yang diijinkan untuk didirikan bangunan pada lahan tersebut adalah luasan lahan yang telah dikurangi dengan garis sempadan pada masingmasing sisi.

Untuk memenuhi persyaratan KDB sebesar 60\%, maka luas lantai dasar atau luasan yang dapat dibangun berubah menjadi $2.150 \mathrm{~m}^{2}$. 
3. Persyaratan Koefisien Lantai Bangunan (KLB)

Koefisien Lantai Bangunan yang diijinkan pada lahan ini adalah sebesar $420 \%$. Sehingga, luasan keseluruhan lantai yang dapat dibangun adalah sebagai berikut.

Luas Lantai = Luas Lahan $\mathrm{x} 420 \%$

$$
\begin{aligned}
& =3584 \times 420 \% \\
& =15052.8 \mathrm{~m}^{2}
\end{aligned}
$$

Jumlah lantai maksimum yang dapat dibangun adalah sebagai berikut.

$\frac{\text { Luas Lantai Bangunan Maksimum }}{\text { Luas Lantai Dasar Bangunan }}=\frac{15052.8}{2150}=7.001=7$ Lantai

Jadi, tinggi maksimum bangunan yang dapat direncanakan adalah tujuh lantai.

Dari hasil perhitungan tersebut, dapat direncanakan total luas lantai yang direncanakan melalui perhitungan berikut.

Luas Total Lantai Rencana

$=$ Luas Lantai Dasar Bangunan x Jumlah Lantai

$=2150 \times 7$

$=15050 \mathrm{~m}^{2}$

4. Persyaratan Koefisien Dasar Hijau (KDH)

Besaran nilai Koefisien Dasar Hijau untuk lahan ini adalah sebesar 20\%. Nilai $\mathrm{KDH}$ merupakan perbandingan antara luasan lahan tidak terbangun dengan luas seluruh lahan. Perhitungan $\mathrm{KDH}$ dapat dilihat sebagai berikut.

Luas lahan sisa

$=$ Luas lahan - Luas Lantai Dasar Bangunan

$=3584-2150$

$=1434 \mathrm{~m}^{2}$

$\mathrm{KDH}=\frac{\text { Luas Lahan Sisa }}{\text { Luas Lahan }}=\frac{1434}{3584}=0.40 \times 100 \%=40 \%$

$40 \%>20 \%$ (memenuhi syarat KDH ijin)

\section{Aspek Finansial}

\section{Biaya Invstasi}

Dalam perencanaan biaya investasi terdiri dari biaya tanah dan biaya konstruksi. Biaya tanah diperoleh dari metode perbandingan pasar sehingga diperoleh biaya tanah sesuai dengan karakteristik tanah yang ditinjau. Biaya konstruksi diperoleh dari perhitungan biaya pembangunan gedung [4]. Besar total biaya investasi tiap aternatif penggunaan dapat dilihat pada Tabel 1 .

Tabel 1.

Biaya Investasi Alternatif Penggunaan

\begin{tabular}{ccc}
\hline \hline Investasi Pertokoan & $\begin{array}{c}\text { Investasi } \\
\text { Perkantoran }\end{array}$ & Investasi Hotel \\
\hline $219,838,170,991.95$ & $206,190,854,770.95$ & $178,896,222,328.95$ \\
\hline \hline
\end{tabular}

Sumber: Hasil Olahan Penulis

\section{Biaya Pendapatan}

Perencanaan biaya pendapatan berasal dari hasil penyewaan properti, pendapatan service charge, dan pendapatan parkir. Besarnya tarif penyewaan properti diperoleh dari pendekatan pasar beberapa properti sejenis. Biaya service charge diperoleh dari $20 \%$ pendapatan sewa properti per tahun [5]. Sedangkan pendapatan parkir diperoleh dari harga tarif parkir dikalikan dengan jumlah kendaraan yang dapat ditampung. Tiap tahunnya biaya pendapatan mengalami kenaikan karena adanya kenaikan tarif sewa properti. Contoh hasil perhitungan biaya pendapatan dapat dilihat pada Tabel 2.
Tabel 2.

Biaya Pendapatan Tiap Alternatif

\begin{tabular}{cccc}
\hline \hline Tahun & $\begin{array}{c}\text { Pendapatan } \\
\text { Pertokoan }\end{array}$ & $\begin{array}{c}\text { Pendapatan } \\
\text { Perkantoran }\end{array}$ & Pendapatan Hotel \\
\hline 2017 & $30,261,579,264$ & $50,747,027,760$ & $37,160,647,603.20$ \\
\hline \hline
\end{tabular}

Sumber: Hasil Olahan Penulis

\section{Biaya Pengeluaran}

Perencanaan biaya pengeluaran terdiri dari biaya pengeluaran air, biaya pengeluaran listrik, dan biaya pemeliharaan. Setiap tahunnya biaya pengeluaran mengalami kenaikan karena kenaikan tarif rencana listrik tiap tahun. Contoh biaya pengeluaran dapat dilihat pada Tabel 3.

Tabel 3.

Biaya Pengeluaran Tiap Alternatif

\begin{tabular}{cccc}
\hline \hline Tahun & $\begin{array}{c}\text { Pengeluaran } \\
\text { Pertokoan }\end{array}$ & $\begin{array}{c}\text { Pengeluaran } \\
\text { Perkantoran }\end{array}$ & $\begin{array}{c}\text { Pengeluaran } \\
\text { Hotel }\end{array}$ \\
\hline 2017 & $7,162,577,305$ & $8,173,925,341$ & $1,997,838,361$ \\
\hline \hline
\end{tabular}

4. Analisis Arus Kas

Analisis arus kas tiap alternatif penggunaan dilakukan dengan metode Net Present Value (NPV). Metode ini dilakukan dengan cara mengurangi pendapatan dengan pengeluaran tiap tahun selama masa investasi sehingga diperoleh aliran kas bersih. Pada akhir masa investasi, terdapat nilai sisa bangunan yang nilainya diperoleh dari hasil pembangian umur efektif bangunan dengan umur manfaat bangunan dikalikan biaya konstruksinya. Arus kas bersih kemudian disesuaikan dengan discount factor yang besarnya diperoleh dari rata-rata tingkat suku bunga \pm tingkat resiko yang diterima, yakni sebesar $12.72 \%$. Nilai NPV bertanda positif mengidentifikasikan bahwa investasi tersebut layak dan sebalikya. Lama investasi yang direncanakan adalah sepuluh tahun.Hasil dari perhitungan aliran kas tiap alternatif penggunaan dapat dilihat pada Tabel 4.

Tabel 4.

Hasil Perhitungan Aliran Kas Alternatif Penggunaan

\begin{tabular}{cccc}
\hline \hline \multirow{2}{*}{ Uraian } & \multicolumn{3}{c}{ Alternatif } \\
\cline { 2 - 4 } & Pertokoan & Perkantoran & Hotel \\
\hline Investasi & $264,960,730,991.95$ & $251,313,414,770.95$ & $224,018,782,328.95$ \\
Pendapatan & $30,261,579,264$ & $50,747,027,760$ & $37,160,647,603$ \\
Pengeluaran & $7,162,577,305$ & $8,173,925,340.84$ & $1,997,838,360.54$ \\
NPV & $-41,661,912,075.79$ & $87,309,250,610.40$ & $66,130,179,267.84$ \\
Kesimpulan & Tidak Layak & Layak & Layak \\
\hline \hline
\end{tabular}

\section{E. Analisis Produktivitas Maksimum}

Alternatif penggunaan yang layak secara legal, fisik, dan finansial, selanjutnya akan dianalisis produktifitas maksimum. Analisis penggunaan maksimal produktif bertujuan untuk mencari nilai lahan dari masing-masing alternatif.

Nilai lahan alternatif penggunaan diperoleh dari nilai properti dikurangi dengan nilai bangunan. Nilai properti diperoleh dengan menggunakan pendekatan pendapatan.. Pendekatan pendapatan dilakukan dengan cara mengurangi pendapatan dengan pengeluaran tiap tahun selama masa investasi sehingga diperoleh aliran kas bersih tanpa memasukkan biaya investasi. Kemudian, besaran Net Operating Income pada akhir masa investasi dibagi dengan tingkat kapitalisasi sehingga diperoleh terminal value. Nilai 
NPV yang diperoleh dari perhitungan pendapatan bersih kemudian dipilih menjadi nilai properti. Nilai bangunan sendiri adalah nilai konstruksi dari alternatif penggunaan. Nilai bangunan perkantoran adalah sebesar Rp 117.594.374.770 dan nilai bangunan hotel adalah sebesar Rp 90.299.742.328.

Nilai properti pertokoan adalah sebesar Rp 406.563.94.841. Hasil perhitungan nilai properti pertokoan dapat dilihat pada Tabel 5. Dengan cara yang sama, nilai properti hotel diperoleh sebesar Rp 345.071.820.301.

Tabel 5.

Hasil Perhitungan Nilai Properti Pertokoan (dalam ribuan rupiah)

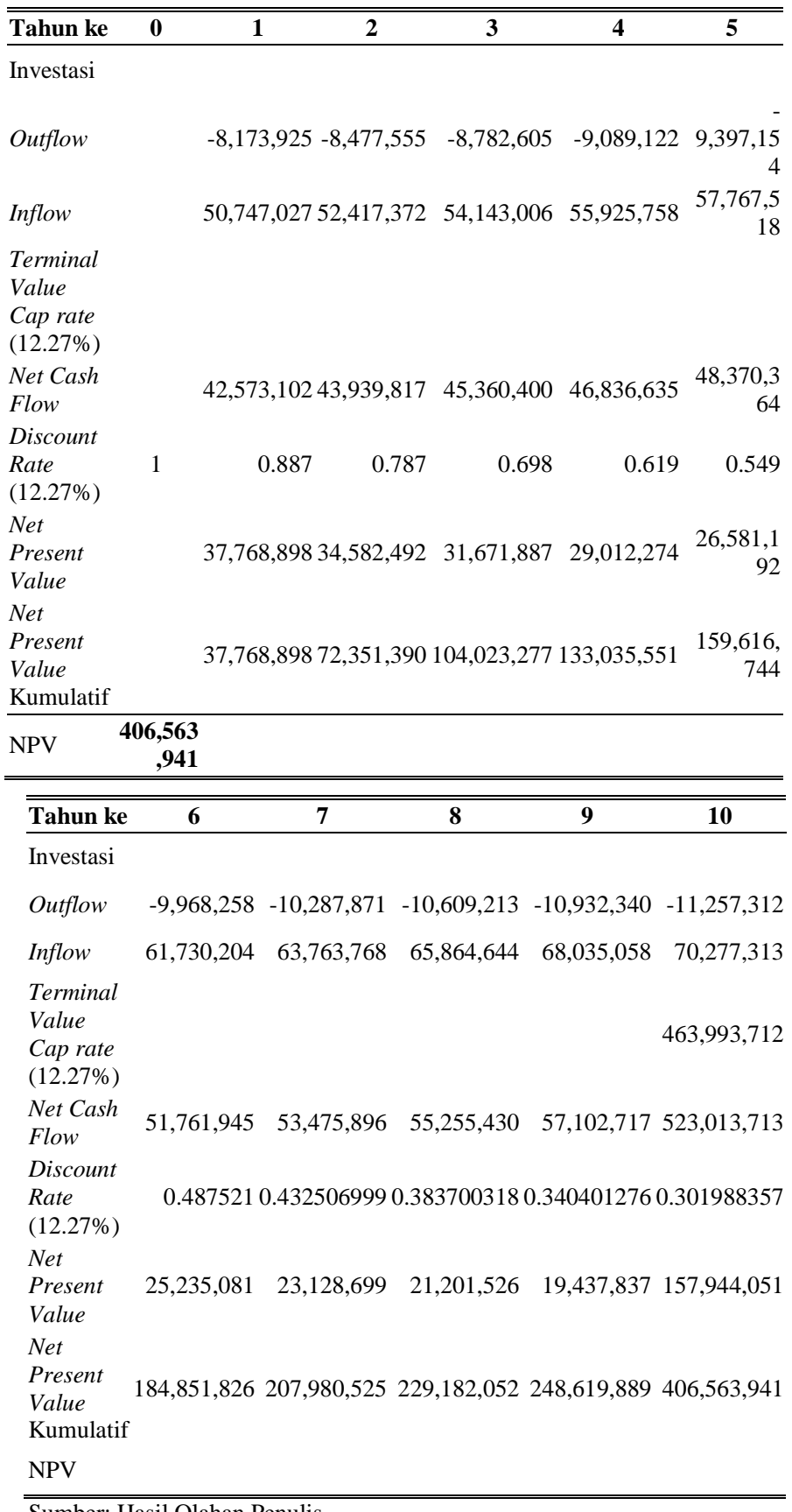

Sumber: Hasil Olahan Penulis

Untuk mendapatkan nilai lahan masing-masing alternatif penggunaan, maka dilakukan pengurangan nilai properti alternatif penggunaan terhadap nilai bangunan alternatif penggunaan. Hasil perhitungan nilai lahan masing-masing alternatif dapat dilihat pada Tabel 6.
Tabel 6.

Nilai Lahan Alternatif Penggunaan

\begin{tabular}{clrr}
\hline \hline No & \multicolumn{1}{c}{ Uraian } & Perkantoran & \multicolumn{1}{c}{ Hotel } \\
\hline 1. & Nilai Properti & $406,563,941,841$ & $345,071,820,301$ \\
2. & Nilai & $117,594,374,770$ & $90,299,742,328$ \\
3. & Ningui Lahan & $288,969,567,070$ & $254,772,077,972$ \\
4. & Nilai lahan $/ \mathrm{m}^{2}$ & $80,627,669$ & $71,085,959$ \\
\hline \hline
\end{tabular}

Dari dua alternatif penggunaan yang telah dianalisis produtktivitas maksimumnya, alternatif penggunaan kantor yang mampu memberikan nilai lahan tertinggi yakni sebesar Rp 80.627.669/m².

\section{KESIMPULAN}

Dari penelitian ini dapat ditarik beberapa kesimpulan antara lain sebagai berikut :

1. Menurut analisis aspek legal, aspek fisik dan pemilihan alternatif, properti komersial yang dapat diperuntukkan pada lahan kosong di Jalan Raya Diponegoro Nomor 110-112 antara lain pertokoan, perkantoran, pusat perbelanjaan, dan hotel.

2. Dari analisis aspek finansial, alternatif properti yang dinyatakan layak adalah perkantoran dan hotel.

3. Dari analisis produktifitas maksimum dapat disimpulkan bahwa pengembangan lahan sebagai properti komersial perkantoran merupakan alternatif penggunaan terbaik bagi lahan objek penelitian karena memiliki nilai lahan sebesar Rp 80.627.669/m²

\section{DAFTAR PUSTAKA}

[1] A. Prawoto, Teori dan Praktek Penilaian Propert Edisi III. Yogyakarta: BPFEE Universitas Gajah Mada, 2015.

[2] B. Hidayawati, W dan Harjanto, Konsep Dasar Penilaian Properti. Yogyakarta: BPFE Universitas Gajah Mada, 2003.

P. Hartono, Utilitas Bangunan. Jakarta: Djambatan, 2002.

[4] K. P. Umum, Peraturan Menteri Pekerjaan Umum Nomor: 45/PRT/M/2007 Tentang Pedoman Teknis Pembangunan Bangunan Gedung Negara. Jakarta, 2007.

[5] J. Jimmy S, Panduan Sistem Bangunan Tinggi Untuk Arsitek dan Praktisi Bangunan. Jakarta: Erlangga, 2005. 